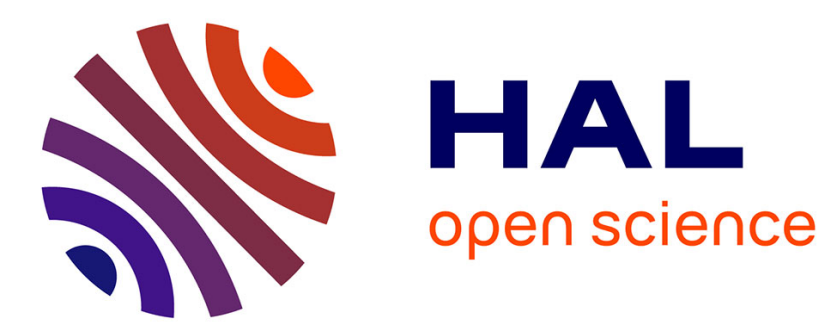

\title{
Monica R. Gisolfi, 2017, The Takeover: Chicken Farming and the Roots of American Agribusiness, Athens, University of Georgia Press, 204 p. \\ Rick Welsh
}

\section{- To cite this version:}

Rick Welsh. Monica R. Gisolfi, 2017, The Takeover: Chicken Farming and the Roots of American Agribusiness, Athens, University of Georgia Press, 204 p.. Review of Agricultural, Food and Environmental Studies, 2017, 98 (4), pp.313-315. 10.1007/s41130-018-0067-8 . hal-03114849

\author{
HAL Id: hal-03114849 \\ https://hal.science/hal-03114849
}

Submitted on 19 Jan 2021

HAL is a multi-disciplinary open access archive for the deposit and dissemination of scientific research documents, whether they are published or not. The documents may come from teaching and research institutions in France or abroad, or from public or private research centers.
L'archive ouverte pluridisciplinaire HAL, est destinée au dépôt et à la diffusion de documents scientifiques de niveau recherche, publiés ou non, émanant des établissements d'enseignement et de recherche français ou étrangers, des laboratoires publics ou privés. 


\title{
Monica R. Gisolfi, 2017, The Takeover: Chicken Farming and the Roots of American Agribusiness, Athens, University of Georgia Press, 204 p.
}

\author{
Rick Welsh ${ }^{1}$
}

Published online: 23 March 2018

(C) INRA and Springer-Verlag France SAS, part of Springer Nature 2018

This succinct history of the poultry industry authored by Professor Monica R. Gisolfi of the University of North Carolina, Wilmington, is divided into four chapters, a foreword, an introduction, and an epilogue. The volume is part of a series entitled Environmental History and the American South and is published by the University of Georgia Press. The foreword is authored by Paul S. Sutter, the founding editor of the series, and is a useful summary of the book. Sutter points out that The Takeover focuses primarily on "the social costs of the rise of poultry production" but also covers the negative environmental consequences of the industry. Indeed, even though the volume is part of an environmental history series, not much attention is paid to environmental issues until the final chapter: From Public Nuisance to Toxic Waste. Also, most of the material concerns the state of Georgia's poultry industry, but implications are drawn nationally and even globally in the epilogue.

Chapter 1 covers the years 1914-1939 and explains how the post-Civil War small farm sector in Upland Georgia evolved from one of diversified cropping systems to cotton monoculture which in turn gave way to poultry farming. Gisolfi argues that creditors refused to finance any enterprise but cotton growing and therefore led to dependency on this crop. The system led predictably to insect and disease pressure as well as glutted markets, bankruptcy, and eventually government intervention through the Agricultural Adjustment Act of 1933. Government payments to landowners to support farm income and reduce acreage in cotton did not often make it to tenants and sharecroppers - though these parties were entitled to the payments. Landowners kept the majority of the government funds and used them in part to expand into poultry production. This expansion was also supported by feed firms seeking markets in the south for poultry feed. Early on, the expansion of the poultry industry developed organically, as traditional poultry production, often managed by women, grew as credit

Rick Welsh

jrwelsh@syr.edu

1 Syracuse University, Syracuse, NY, USA 
and feed became more available. Poultry growers began eventually to use brokers instead of handling marketing themselves, and thus the process of growers focusing solely on raising birds and neglecting the remainder of the commodity system was introduced.

Chapter 2 on World War II and the Command Economy outlines the shift in the industry from increases in government contracts to feed the expanding military. Government sourcing of poultry brought with it quality controls and regulatory imperatives that made it difficult for smaller growers and processing firms to compete with larger, better financed firms. Gisolfi asserts that this dynamic was compounded by the larger firms being well connected with the parties establishing procurement policies and thus having input into the development of regulations better suited for larger firms. Gisolfi also points out that the poultry production, processing and distribution system were peopled only by Whites, as African-American farmers were not invited into the system. In addition, as the industry grew in size and concentration, federal government funding of research to undergird larger-scale production and processing facilitated the shift toward an industrial model. Therefore, government increased effective demand for poultry produced and processed under specific quality controls, and also produced the science and technology to make meeting these quality standards possible.

Chapters 3 (Taking Over: Integrators and the Birth of the Modern Poultry Industry) and 4 (Broiler Sharecroppers and Hired Hands) document the rise of the modern poultry industry still present today and expanding globally. Gisolfi's primary argument in these chapters is that integrating firms entangled farmers in a fundamentally unfair system by the use of feed-conversion contracts. These contracts are structured such that production decisions reside with integrating firms but production risks, such as the provision of land and labor and investment in buildings and equipment and disposal of dead birds and litter reside with the farmers. Integrating firms control the contract terms regarding compensation based on converting feed into chicken meat as well as the quality of the feed provided, access to retail markets and consumers, and dictating the size and structure of the poultry housing and feeding equipment and regimes. Constantly requiring "updating and modernization" of the housing and equipment forces poultry growers into debt and into off-farm work to pay for the "improvements" and service debt. In turn, full-time poultry growing becomes a sideline in which off-farm labor subsidizes the integrating firms who reap the vast majority of the value from the poultry commodity chain.

Chapter 5 on Public Nuisance to Toxic Waste explains the environmental consequences of saddling poultry growers with the responsibility of dead bird and poultry litter disposal in an expanding and concentrating industry since the growers have the fewest financial resources of the actors in the poultry commodity chain to deal with such waste products. In addition, as processing plants increase in size and handle more birds, the firms overburden public waste and sewage systems and create environmental hazards for the public. The title of the chapter stems from the historical fact that citizens had only public nuisance laws to provide protections from environmental hazards from agricultural operations until the environmental regulatory state included agriculture in its portfolio during the 1990s.

Overall, this is a short and informative volume that would be a good addition to a course on food systems or the historical development of US agriculture or the livestock industry. Interestingly, for being so brief, about 72 pages of text, chapters 3 and 4 
contain a surprising amount of redundant material as Gisolfi tends to repeat the main argument involving industry structural change and the social, economic, and environmental consequences engendered by the introduction of the feed-conversion contract. Also, there are not a lot of new findings or arguments in the book that have not been printed elsewhere. Rather, Gisolfi's primary contribution is that she houses the major criticisms of the historical development, and current trajectory, of the poultry industry in a compact and accessible volume that tells a compelling story.

Rick Welsh, Syracuse University 